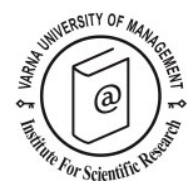

\title{
Profile of practice, travel behaviour and motivations for geocaching
}

\author{
Ana Lúcia Falcão ${ }^{1}$, António Sérgio Damásio ${ }^{2}$ and Ricardo Melo ${ }^{3 *}$
}

Received: 15/06/2015 Accepted: 21/11/2016

\footnotetext{
1 Polytechnic Institute of Coimbra, Coimbra Education School, Coimbra, Portugal; E-mail: lucia_falcao84@hotmail.com

2 Polytechnic Institute of Coimbra, Coimbra Education School, ASSERT, Coimbra, Portugal; E-mail: sergio@esec.pt

${ }^{3}$ Polytechnic Institute of Coimbra, Coimbra Education School, ASSERT, IRNIST, Rua Dom João III, Solum, 3030-329 Coimbra, Portugal; Phone: 00351239793 120; E-mail: ricardo.es.melo@gmail.com

* Corresponding author
}

\begin{abstract}
Geocaching is a recreational sport activity considered as a postmodern treasure hunting game. Associated with the movement to distant places, the search for new landscapes, culture and adventure, geocaching is being integrated into the tourism industry. In spite of its growth and economic significance, few studies have been developed to understand this sport tourism activity. Thus, this study was developed to understand the geocaching practice profile, geocaching travel behaviour and the motivations for the practice of geocaching, and to examine whether these variables are associated with the socio-demographic characteristics of geocachers. An online questionnaire survey was applied to geocachers living in Portugal, and 613 responses were obtained. The results show that geocaching is a recent sport activity in Portugal, whose motivations for practice are related to nature and escape, and that geocachers have a strong disposition to travel, highlighting the potential of geocaching for sport tourism. Statistical tests also revealed that socio-demographic characteristics are not associated with the geocaching practice profile and geocaching travel behaviour. However, the socio-demographic characteristics are associated with the motivations for the practice of geocaching, particularly when compared by sex, age and education level. Management and marketing implications for sport tourism operators and destinations are discussed.
\end{abstract}

(C) 2017 Varna University of Management. All rights reserved

Keywords: geocaching, motivations, practice profile, sport tourism, travel behaviour.

Citation: Falcão, A., A. Damásio and R. Melo (2017) Profile of practice, travel behaviour and motivations for geocaching. European Journal of Tourism Research 16 pp. 92-107

\section{Introduction}

Geocaching and sport tourism

The reach of technological devices and digital technology is remarkable. In postmodern society, mobile communication devices, such as cell phones, are ubiquitous. The International Telecommunication Union (2015) estimates that there are more than 7.2 billion 
mobile-cellular phone subscriptions worldwide and 3.2 billion internet users. With this in mind, several authors support the idea that electronic technology such as televisions, computers, tablets, smart phones and similar devices create a disconnection between the user and the natural environment (Louv, 2008; Pergams \& Zaradic, 2006; Singer, Singer, D'Agostino \& Delong, 2009). On the other hand, some applications for mobile digital technology may allow users to connect to the natural environment in unique and curious ways (Ihamäki \& Tuomi, 2009). An example of the application of digital technology that seems to support the relationship between technology and natural places is the outdoor geo-location sport called geocaching (Ihamaki, 2015). Geolocation is a method for determining the location of an individual in relation to a geographical system, such as the latitude and longitude (coordinates) of a map. In the particular case of geocaching, participants (called geocachers) use Global Positioning System (GPS) enabled devices to navigate to a specific set of GPS coordinates to try to find a container (called a geocache) hidden in that location (Boulaire \& Hervet, 2012; Groundspeak, 2014). Geocaching is a highly technological, world spanning, recreational sport activity, considered as a postmodern treasure hunting game (Lary, 2004). The basic premise of this game is that individuals or groups (called owners) create and hide geocaches anywhere in the world, recording and publishing the GPS coordinates and the description of the caches in a geocaching website (e.g., www.geocaching.com). After publication, other geocachers can download the GPS coordinates from the geocaching website to a mobile GPS receiver (GPSr), helping to guide them in the search of the geocache (Groundspeak, 2014). The fundamental rules of traditional form of geocaching are: 1) take an item from the cache once the cache was found; 2) leave another item in the cache container in place of the old item, and; 3) log the information in the log book within the cache container (Groundspeak, 2014).

Geocaching incorporates a set of games where different caches can be found and/or hidden (Groundspeak, 2014), such as: $\checkmark$ Traditional Caches - is the original type of geocache and the most straightforward. It consists of a container and a log book. Larger containers may also carry swag and/or trackables. The coordinates listed on the traditional cache page are the exact location of the cache;

$\checkmark$ Mystery or Puzzle Caches - this form of cache can involve complicated puzzles that can be first solved to determine the coordinates. Due to the increasing creativity of geocaching this becomes the starting ground for new and unique challenges;

$\checkmark$ Multi-cache - involves two or more locations, the final location being a physical container with a logbook inside. There are many variations, but most multi-caches have a hint to find the second cache, and the second cache has hints to the third, and so on;

$\checkmark$ Earth Cache - is a special geological location that people can visit to learn about a unique feature of the Earth. EarthCache pages include a set of educational notes and the details about where to find the location (latitude and longitude). Visitors to EarthCaches can see how our planet has been shaped by geological processes, how we manage its resources and how scientists gather evidence. Typically, to log an EarthCache, you will have to provide answers to questions by observing the geological location;

$\checkmark$ Letterbox Hybrid - is another form of treasure hunting that uses clues instead of coordinates. In some cases, the letterbox owner has made their container both a letterbox and a geocache and posted its coordinates on Geocaching.com. These types of geocaches will contain a stamp that is meant to remain in the box and is used by letterboxers to record their visit;

$\checkmark$ Wherigo cache - is a toolset for creating and playing GPS-enabled adventures in the real world. By integrating a Wherigo experience, called a cartridge, with finding a geocache, the geocaching hunt can be an even richer experience. Among other uses, Wherigo allows geocachers to interact with physical and virtual elements such as objects or characters while still finding a physical geocache container. A Wherigo-enabled GPS device is required to play a cartridge;

$\checkmark$ Virtual Cache - is a cache that exists in a form of a location. It is about discovering a 
location rather than a container. A virtual cache could be to answer a question about a location, an interesting spot, a task, etc... The reward for these caches is the location itself and sharing the information about the visit. The geocachers must visit the location and acquire the coordinates there before they can post. Although many locations are interesting, a Virtual Cache should be out of the ordinary enough to warrant logging a visit.

In addition to the typology, geocaches present four different sizes, from microcaches (less than $100 \mathrm{ml}$ ) such as photographic film boxes, to large geocaches (over 20L), such as larger containers (Groundspeak, 2014). Geoaches are also classified according to the degree of difficulty, from one to five. A level one cache is located in a very accessible location and the cache is easily found, unlike a level five cache that is placed in a difficult to reach location, the cache is very well camouflaged and difficult to find (Groundspeak, 2014). The treasure, usually placed inside waterproof and camouflaged containers, generally consists of items such as toys, stickers, small trinkets, among others (Lary, 2004; Shaunessy \& Page, 2006).

Geocaching begins in the year of 2000 , with the placing of the first geocache in Portland, United States, after the civil availability of the GPS. Geocaching has since been disseminated worldwide (Cameron, 2011) and, nowadays, it is estimated that exists around 6 millions of geocachers and about 2.4 million geocaches available around the world (Groundspeak, 2014). The game's popularity can be explained, in part, because of both its accessibility through the internet and its appeal to technology, and to the growing demand for outdoor exploration and discovery (Sherman, 2004).

Geocaching is more than a simple game of discovery and register of an object in the landscape, it is a territorial activity that allows a trip for different destinations where geocachers seek new landscapes, culture and adventure (Fernandes, 2013), allowing an overnight stay and a tourist consumption. In this regard, Ihamaki (2015) states that "Geocaching is an emerging tourism activity and the perfect way to explore less known tourist sites and experience the great outdoors at any time of year" (p. 23). It is an activity that allows geocachers to share their positive and memorable geocaching experience and introduce new and creative tourism services and events (Ihamaki, 2012). Geocaching is also often used to access difficult places that require special skills (Boulaire \& Hervet, 2012) including those required in various nature sports (tourism) activities such as rockclimbing, mountaineering, canyoning, among others. Considering this, geocaching was integrated into the sport tourism sector.

Geocaching potential was observed and Geocaching.com website added a "Geocaching for Tourism" menu in 2012 (Ihamaki, 2015). With this development, some geocaching products related with tourism were launched, such as:

$\checkmark$ Geo Tours - are structured itineraries that can guide geocachers in a particular region or natural park, allowing tourists to know points of interest of the region, which are example, a natural or built monument, a typical restaurant that offers the local cuisine, a panoramic view or even a local for overnight, allowing also the contact with the local population. Geo Tours or Geo Trails can be followed by both accomplished athletes and families, by foot, bicycle or ride (Boulaire \& Hervet, 2012);

$\checkmark$ Geo Events - are meetings of geocachers. These events can have different dimensions: Events (less than 500 geocachers); Mega Events (with more than 500 geocachers) and; Giga Events (with more than 5000 geocachers). Geo Events offer between one to several days of planned activities. Large events can attract geocachers from all over the world and are usually held annually. This type of Geo Events can be promoted to a year in advance to allow their dissemination to a greater number of participants (Groundspeak, 2014).

Geocaching can also be used in different ways to promote tourism in the territories (Boulaire \& Hervet, 2012): i) promoting geocaching can allow to promote the territory, demonstrating the potential of the region to offer interesting and varied experiences for geocachers; and ii) promoting a territory and use the geocaching as a way to discover it. In this regard, Groundspeak (2014) estimates that every \$1 
spent by a tourist destination on geocaching will result in about $\$ 20$ spent by tourist on hotels, restaurants and the like.

\section{Geocaching studies}

With an increase in popularity over the last 16 years, geocaching has gained attention as an area of academic interest. However, as stated by Ihamäki and Luimula (2014), "There is a lack of extensive research on this game, and there is a need for more academic research on this game and its application to other contexts worldwide" (p. 127).

The earliest known geocaching studies were conducted in 2004 by Chavez and Schneider (Chavez, Courtright \& Schneider, 2004; Chavez, Schneider \& Powell, 2004), who investigated the involvement in geocaching activities focusing on the demographics and motivation of the participants. One year later, Trotman, Jones, and Handley (2005) presented the logs recorded by geocachers on the South Island (150 km2) of New Zealand, and looked into the distance that 12 South Island players needed to travel from their homes to geocaches. In 2006, Kelley presented the world of geocaching communities across the United States, and their ability to integrate new technologies within natural settings (Kelley, 2006).

In 2007, Ihamäki described what geocaching is and presented an analysis of a case study on how geocaching can be used as a rewarding approach in teaching GPS technology in education (Ihamäki, 2007). Similar approaches had emphasised the benefits of integrating new technologies such as the GPS (and geocaching) in the informal learning (e.g., Clough, 2010), or in formal education (e.g., Broda, 2007; Lary 2004; Ihamäki, 2014, 2015; Mayben 2010; McCarthy \& McCarthy, 2005; Trimpe \& Hughes 2005).

Several other studies also explored the touristic potential of the geocaching activities (e.g., Boulaire \& Hervet 2012; Ihamäki, 2008, 2012, 2013, 2015; Reams \& West, 2008). The study developed by Reams and West (2008) looked at geocaching from a creative tourism experience perspective, presenting a pilot study in Acadia National Park. Similar, Ihamäki
(2008) presented an analysis of a case study, discussing how and where to use geocaching as experience tourism products, dealing with a case study, in Finland zone of Pori, which is a service for tourists using geocaching in experience production. Later, Ihamäki (2012, 2013) also presented results concerning the creative experience of geocaching in the tourism context. On the other hand, Boulaire and Hervet (2012) highlighted and concepttualize the potential of geocaching for tourism by describing characteristics from which this new itinerancy have emerged. Motivation is also a hot topic in the study of geocaching participation (e.g., Chavez, Courtright \& Schneider, 2004; Chavez, Schneider \& Powell, 2004; O'Hara, 2008; Schneider, Silverberg \& Chavez, 2011) as we can see in the next section.

\section{Geocaching motivations}

Motivation is one of the most important frameworks to understand sport tourism participation (Melo, 2017). Motivation can be defined as the global integrating network of biological and cultural forces, which gives value and direction to travel choices, behaviours and experiences (Pearce, Morrison \& Rutledge, 1998), integrating both push and pull factors (Crompton, 1979). Push factors represent socio-psychological motives that drive people to travel or to participate in some sport tourism activities, such as geocaching, and when the general decision to participate is made, pull factors motivate tourist to choose a specific destination. Motivations are thus a fundamental concept in sport and tourism literature because they are seen as a major influence in the destination choice.

Destination choice can be expected to be influenced by a complex set of motivations, both general tourism motivations as well as specific sport-related motivation (Robinson \& Gammon, 2004). This motivation differ depending on the activity (Flucker \& Turner, 2000), but also due to the importance that sport has on vacation (Weed \& Bull, 2004). Considering geocaching as a nature sports activity, belonging to the active sport tourism segment, motivations for participating in such activities must be viewed at the intersection and influence that tourism and sports motives 
have upon each other. Robinson and Gammon (2004) have presented two areas of focus which mean differentiating between: i) those who travel primarily to participate in sports, such as geocaching; and ii) those for whom sport is perceived as a secondary consideration. Although tourism and sport can be considered as separate activities, involving a complex set of motivations, both sports participation and tourism share a number of common traits which may offer some insights into the uniqueness of the sports tourist (Weed \& Bull, 2004; Reeves, 2000) and geocaching participants.

Several studies have been conducted about motivation for participation in different nature sports activities, including, equestrian activities (Daniels \& Norman, 2005), kite surfing and windsurfing (Hennigs \& Hallmann, 2014), paragliding (Chang \& Huang, 2012), rockclimbing (Woratschek, Hannich, \& Ritchie, 2007), sea kayaking (O'Connell, 2010), surfing (Reynolds \& Hritz, 2012), white-water rafting (Flucker \& Turner, 2000), and other outdoor activities (Wang, Ang, Teo-Koh, \& Kahlid, 2004; Festeu, 2002, Sugerman, 2001). Melo and Gomes (2017) conducted an empirical work to study the motivations for participating in 23 different nature sports activities, divided into six dimensions: i) nature/environment - to be in contact with nature; to enjoy nature and the landscape; to protect the environment; ii) risk/adventure - to have new experiences/adventure sensations; to challenge ability; to put yourself to the test; iii) sociability - to occupy free time; to interact with other people/social interaction; because of the socializing context it provides; iv) hygienism medical advice/health issues; for maintaining and/or enhancing physical condition; relaxation/break from the everyday routine; v) competition - to be involved in a sports competition; and vi) tourism - to visit other sites/destinations; to learn about other traditions and other cultures; to visit and defend heritage. Generally, for all of the participants of the 23 activities, the nature/environment and risk/adventure dimensions were the most significant motivational factors for participating in nature sports activities, demonstrating the significance of these two elements in nature sports participation (Melo \& Gomes, 2017).
Buckley (2012) identified, in the $\sim 50$ studies he reviewed, at least 14 different categories of motivations for participating in nature sports and adventure activities, which he divided into 3 dimensions: i) internal, performance of activity ("thrill", "fear", "control", "skills", "achievement", "fitness", and "risk"); ii) internal/external, place in nature ("nature", "art", "spirit"); and iii) external, social position ("friends", "image", "escape", and "compete").

O'Hara's (2008) research on understanding the practices and motivations of geocachers, based on a diary and in-depth interviews, points to five different pull motivations: social walking; collecting; profile and statistics; first to find; competition and urgency; challenge; individual and social aspects. On other hand, in the empirical study on geocaching motivations of Schneider, Silverberg and Chavez (2011), seven expected benefits (pull factors) emerged from the 26 investigated items: physical fitness, nature experiences, learning, stimulation, relaxation, autonomy, and socialization.

\section{Purpose and objectives of the study}

Geocaching emerged during the last few years as the result of cultural, technological and geographical innovations which created new strolling practices (Boulaire \& Hervet, 2012). Currently it is estimated that there are 2 million geocahers worldwide (Groundspeak, 2014). Portugal accompanied the geocaching growth movement, estimating that in 2013 there were more than 35 thousand geocachers in the country (Geopt, 2014). In spite of the size and economic implications of geocaching, few studies have examined this form of sport tourism and even fewer investigated the motivation for the practice of geocaching. The study of the motivations in sport and tourism, and in geocaching in particular, is important because it allows the understanding of the participants' behaviour enabling the adjustment of an adequate offer.

Aiming to fill such a gap in the literature, this study addresses three main objectives: i) to identify the socio-demographic characteristics of geocachers, geocaching practice profile and geocaching travel behaviour; ii) to understand the motivations of geocachers to participate in geocaching activities; and iii) to examine 
differences in geocaching practice profile, geocaching travel behaviour and the motivations for the practice of geocaching between the different socio-demographic characteristics of geocachers.

\section{Methodology}

An online survey questionnaire was used to collect data. The instrument was composed of 22 questions, including socio-demographic characteristics (sex, age, education level, working situation and income), geocaching practice profile (number of years practicing, how began to practice geocaching, companionship, frequency, period of the year, number of geocaches found, number of geoevents they have participated, principal typology of geocaches found), geocaching travel behaviour (travel with intention to practice geocaching, number of travel in the last 12 months, planning of travel, and willingness to take a travel for geocaching in the future) and 26 motivation items adapted from Schneider, Silverberg and Chavez (2011), measured in a 7-point scale, ranging from 1 (nothing important) to 7 (totally important). The questionnaire was validated by pre-test application and expert examination (face validity). The questionnaire was built in Google Forms platform and a casual sample technique was used (Marôco, 2011).

The target population included those who have practiced geocaching activities in Portugal, and who were aged 18 years or older. The questionnaire was distributed in Portugal through websites and social media, and more precisely through geopt.org forum and geocaching groups' Facebook page. The questionnaire was applied from June until July 2014, and 613 answers were obtained.

Data gathered through the questionnaires was subjected to statistical treatment using Statistical Package for Social Sciences software (SPSS v.21, SPSS Inc., Chicago, IL). Results were presented through descriptive statistics using means and standard deviations

Table 1. Sex, age, education level, employment and income indicators of participating Geocahers.

\begin{tabular}{lll}
\hline Sociodemographic indicators & $\mathrm{N}$ & $\%$ \\
\hline Sex & 379 & $61.8 \%$ \\
Male & 234 & $38.2 \%$ \\
Female & & \\
Age group & 322 & $52.5 \%$ \\
$18-30$ & 227 & $37 \%$ \\
$31-43$ & 53 & $8.6 \%$ \\
$44-56$ & 11 & $1.8 \%$ \\
$>56$ & $31( \pm 0.5)$ & \\
Age (mean in years and std. dev.) & & \\
Education Level & 50 & $8.2 \%$ \\
Basic education (9th grade) & 245 & $40 \%$ \\
Secondary education (12 & \\
Graduate degree & 249 & $40.6 \%$ \\
Master or doctorate degree & 69 & $11.3 \%$ \\
Working situation & & \\
Working to others & 355 & $57.6 \%$ \\
Owners of companies or self employees & 64 & $10.4 \%$ \\
Student & 122 & $19.9 \%$ \\
Others & 72 & $12.1 \%$ \\
Income & & $11.1 \%$ \\
Without income & 68 & $7.8 \%$ \\
$\leq € 500$ & $64.2 \%$ \\
$501-€ 1000$ & 48 & $19.7 \%$ \\
$€ 1001-€ 1500$ & 271 & $8.3 \%$ \\
$>€ 1500$ & 121 & $8.8 \%$ \\
Don't know / Don't answer & 51 & 54 \\
\hline
\end{tabular}


for continuous variables, and percentages for nominal and ordinal variables (Marôco, 2011).

Measures of association were based on Chisquare, estimating the degree of association between variables through the Contingency Coefficient and Cramer's V, as described in Marôco (2011). Standardized Adjusted Residuals (SAR) were used to identify cells in the contingency table with significantly different behaviours from expected behaviours between variables. To explain the relationship between the categories of the variables, the residuals of less than -1.96 or greater than 1.96 were used (Pestana \& Gageiro, 2003, p. 140).

Factorial analysis, by Principal Component Analysis (PCA), was used for data reduction purposes (Marôco, 2011). Geocaching motivation (26 items) was reduced to a smaller number of dimensions or PC (five dimensions). The following criteria were used to decide the number of components to extract (Marôco, 2011): i) Kaiser-Meyer-Olkin (KMO) value obtained greater than 0.6 and the significance value (using Bartlett test) below 0.1, in order to reject the null hypothesis and prove the suitability of the analytical method for the treatment of data; ii) eigenvalue greater than 1.0 or the scree Plot indicating the suitable number of PC that can be extracted before the amount of explained variance becomes too small; iii) communalities, representing the percentage of common variance between items and extracted factors; iv) factor loadings, higher than 40\%; and v) variance explained percentage, at least $60 \%$ of the total variance was considered satisfactory. In addition, the reliability coefficient to assess internal consistency (Cronbach's alpha coefficient) was analysed for all dimensions and globally structured (Marôco, 2011).

One-way ANOVA was used to investigate differences between sociodemographic characteristics when analysing the five geocaching motivation dimensions. Kolmogorov-Smirnov test with Lilliefors correction was used to evaluate the assumption of normality of the dependent variable in each independent variable in samples higher than 30 . If the assumption of normality was not observed, the Central Limit Theorem for samples with more than 30 cases was assumed. Levene statistical test was used to verify the assumption of homogeneity and Tukey HSD post-hoc test was used to verify the statistical differences between groups when this assumption was verified. Games-Howell post-hoc test was used when the assumption of the homogeneity was not verified (Marôco, 2011).

\section{Results and discussion}

Geocachers sociodemographic characteristics

The majority of respondents $(61.8 \%)$ of our sample were male (Table 1), which is consistent with the predominant male participation in nature sports in Portugal (Melo \& Gomes, 2017). A large proportion of respondents $(52.5 \%)$ were young adults aged between 18 and 30 years, and more than a third $(37 \%)$ aged between 31 and 43 years, and only a small proportion $(10.4 \%)$ were at least 44 year $(M=31.2 \pm 9.2)$. These results are also consistent with other results presented in the literature (Melo \& Gomes, 2017).

The majority of geocachers $(51.9 \%)$ stated that they had achieved academic qualifications at higher education level, and a large proportion $(40 \%)$ had secondary education level, which means that this group have an education level very above the average of the Portuguese population. Consistent with the higher education levels and the large proportion of workers for others $(56.6 \%)$, and owners of companies or self-employees (10.4\%), the most part of responding geocachers (44.2\%) indicated that had income according to the Portuguese average (between $€ 500-€ 1000$ ), or above $€ 1000$ (20\%). These results are also consistent with high levels of higher education and income among nature sports participants already reported in the literature (Melo, 2013).

Geocaching practice profile and travel behaviour of respondents

Geocaching practice profile of respondents is summarized in Table 2 . The results show that the vast majority of the individuals of the sample (72.4) were beginners ( 1 to 4 years) in the practice of geocaching $(M=2.7 ; S D=2.2)$. Only one individual began the practice of geocaching in 2001, the year of establishment of this activity in Portugal. The data also show that there was from the year of 2010 that the 
number of geocachers has increased in Portugal. Most respondents (81.9\%) were influenced by their social group (friends, colleagues or family) to start practicing geocaching, and generally $(48.5 \%)$ they practice accompanied by individuals of this

Table 2. Geocaching practice profile of respondents.

\begin{tabular}{|c|c|c|}
\hline Indicators of geocaching practice profile & $\mathrm{N}$ & $\%$ \\
\hline \multicolumn{3}{|l|}{ Number of years practicing geocaching (from 2001 to 2014) } \\
\hline 0 years & 58 & 9.5 \\
\hline $1-4$ years & 444 & 72.4 \\
\hline $5-9$ years & 105 & 17.1 \\
\hline $10-13$ years & 6 & 1 \\
\hline \multicolumn{3}{|l|}{ How began to practice geocaching } \\
\hline Occasionally found a geocache & 10 & 1.6 \\
\hline By social communication (e.g., TV, radio, internet, etc.) & 70 & 11.4 \\
\hline $\begin{array}{l}\text { By specialized channels of the sector (e.g., geomagazine journal, geocaching.com } \\
\text { site, etc.) }\end{array}$ & 12 & 2.0 \\
\hline By friends, colleagues or family & 502 & 81.9 \\
\hline Others & 19 & 3.1 \\
\hline \multicolumn{3}{|l|}{ Companionship } \\
\hline Alone & 85 & 13.9 \\
\hline With the partner & 231 & 37.7 \\
\hline In team (group of friends, colleagues or family) & 297 & 48.5 \\
\hline \multicolumn{3}{|l|}{ Frequency of practice } \\
\hline Only during holidays & 78 & 12.7 \\
\hline Sporadically, without regular frequency (e.g., only 1 time per year) & 85 & 13.9 \\
\hline At least 1 way per month & 199 & 32.5 \\
\hline Between 1 and 2 days per week & 197 & 32.1 \\
\hline 3 days or more per week & 54 & 8.8 \\
\hline \multicolumn{3}{|l|}{ Period of the year } \\
\hline Spring & 46 & 7.5 \\
\hline Summer & 155 & 25.3 \\
\hline Autumn & 7 & 1.1 \\
\hline Winter & 5 & 0.8 \\
\hline Along the year & 400 & 65.3 \\
\hline \multicolumn{3}{|l|}{ Number of geocaches found } \\
\hline 0 & 1 & 0.2 \\
\hline $1-250$ & 279 & 45.5 \\
\hline $251-500$ & 113 & 18.4 \\
\hline $501-750$ & 68 & 11.1 \\
\hline $751-1000$ & 31 & 5.1 \\
\hline$>1000$ & 121 & 19.7 \\
\hline \multicolumn{3}{|l|}{ Number of GeoEvents participation } \\
\hline 0 & 214 & 34.9 \\
\hline $1-25$ & 327 & 53.3 \\
\hline $26-50$ & 43 & 7.0 \\
\hline $51-75$ & 12 & 2.0 \\
\hline $76-100$ & 9 & 1.5 \\
\hline$>100$ & 8 & 1.3 \\
\hline \multicolumn{3}{|l|}{ Principal typology of geocaches found } \\
\hline Traditional & 565 & 92.2 \\
\hline Multicache & 28 & 4.6 \\
\hline Letterbox & 3 & 0.5 \\
\hline Mystery Geocache & 9 & 1.5 \\
\hline Earthcache & 2 & 0.3 \\
\hline Events & 4 & 0.7 \\
\hline All & 2 & 0.3 \\
\hline
\end{tabular}


group (friends, colleagues or family) or with their partner $(37.7 \%)$. These results allow suggesting that this activity is strongly related with sociability. Data also show that geocachers found mainly (45.5\%) between 1250 caches, and the main typology found is traditional geocaches $(92.2 \%)$, reinforcing the idea of beginner geocachers. The participation in geoevents are also low, situated mainly (53.3\%) between $1-25$ events.

Statistical tests show few week associations between socio-demographic characteristics and geocaching profile. As far for sex variable, results show statistically significant differences in companionship to practice between men and women ( $p$-value $=0.001$ and Cramers' $V=$ 0.252 ), where were observed that men present a higher predisposition to practice geocaching alone $(S A R=6.1)$ when comparing with women, while women present a higher tendency than men to practice with their partner $(S A R=3.1)$. Data also show statistically significant differences between men and women in the frequency of practice ( $p$-value $=0.001$ and Cramers' $V=0.180)$, in the number of caches found ( $p$-value $=0.006$ and Cramers' $V=0.158)$, and in the number of geoevents they have participated ( $p$-value $=0.002$ and Cramers' $V=$ 0.176 ), where was observed that men present a higher frequency then women to practice geocaching, a higher predisposition to find more caches, and to participate in more geoevents. Results also show that older geocachers are the ones who in general present a higher number of years practicing geocacher ( $p$-value $=0.005$ and Cramers' $V=$ $0.127)$. As regards the beginning of the practice of geocaching ( $p$-value $=0.011$ and Cramers' $V$ $=0.130$ ), the younger group of geocachers are the ones who present a higher predisposition to begin the practice because of their group of sociability $(S A R=4.7)$, while the other groups present a lower tendency to start because of their group of sociability and a higher tendency to begin to practice geocaching because of the information provided by social communication. Statistically significant results were also found between age groups and companionship ( $p$ value $=0.001$ and Cramers' $V=0.163$ ). Younger geocachers (between 18-30 years) present a higher tendency than the others to practice with their partner $(S A R=2.3)$ and a lower tendency to practice alone $(S A R=3.7)$, the group between 31-43 years old present a lower predisposition than the other to practice with their partner $(S A R=-2.2)$, while the group between 44-56 year old present a higher predisposition to practice alone $(\mathrm{SAR}=4.4)$ and a lower predisposition to practice with their group of sociability (SAR=-2.2). As expected, in general older geocachers are also the ones who found more geocaches ( $p$-value $=0.001$ and Cramers' $V=0.210$ ) and have participated in more geoevents ( $p$-value $=0.001$ and Cramers' $V=0.194$ ). As far for other sociodemographic variables, results are not significant.

The vast majority of respondents had taken a travel to practice geocaching in the past $(96.1 \%)$ or reported to be willing, very willing or totally willing to take a geocaching trip in the near future $(79.8 \%)$, highlighting the potential of geocaching for sport tourism. The majority $(55.0 \%)$ reported had taken more than three geocaching trips during the year of 2013 and $10.9 \%$ indicated they had taken more than 10 trips, and mainly (86.1\%) choose the destination previously and then make a search for geocaches in the destination (Table 3).

Statistical tests also show few week associations between sociodemographic characteristics and geocaching travel behaviour. Considering sex variables, only statistically significant differences was found between travel planning ( $p$-value $=0.008$ and Cramers' $V=0.145$ ), where is shown that women $(\mathrm{SAR}=2.2)$ present a higher predisposition that men to choose the destination previously and then make a search for geocaches in the destination, while men $(\mathrm{SAR}=2.3)$ present a higher predisposition then women to choose the destination because of the geocaches searched. In what concerts to age groups, only statistically significant differences were found between age and travel with intention to practice geocaching ( $p$ value $=0.049$ and Cramers' $V=0.102$ ), where is shown that the younger group $(S A R=2.6)$ present a lower predisposition than the other to never made a travel with the main intention to practice geocaching, but to practice geocaching during their travels, the group between $31-43$ years old $(S A R=2.2)$ present a 
Table 3. Geocaching travel behaviour among respondents.

\begin{tabular}{|c|c|c|}
\hline Indicator of geocaching travel behaviour & $\mathbf{N}$ & $\%$ \\
\hline \multicolumn{3}{|l|}{ Travel with intention to practice geocaching } \\
\hline Yes, I already made a travel with the main intention to practice geocaching & 307 & 50.1 \\
\hline $\begin{array}{l}\text { No, I never made a travel with the main intention to practice geocaching, but I } \\
\text { practice geocaching during my travels }\end{array}$ & 282 & 46 \\
\hline $\begin{array}{l}\text { No, I never made a travel with the main intention to practice geocaching, and I don't } \\
\text { practice geocaching during my travels }\end{array}$ & 24 & 3.9 \\
\hline \multicolumn{3}{|l|}{ Number of travel in the last 12 months $(\mathrm{N}=589)$} \\
\hline 0 & 62 & 10.5 \\
\hline $1-2$ & 203 & 34.5 \\
\hline $3-5$ & 172 & 29.2 \\
\hline $6-10$ & 88 & 14.9 \\
\hline $11-20$ & 33 & 5.6 \\
\hline$>20$ & 31 & 5.3 \\
\hline \multicolumn{3}{|l|}{ Planning of travel for Geocaching $(\mathrm{N}=589)$} \\
\hline $\begin{array}{l}\text { Choose the destination previously and then make a search for geocaches in the } \\
\text { destination }\end{array}$ & 507 & 86.1 \\
\hline Choose the destination because of the geocaches searched & 72 & 12.2 \\
\hline Make the choice through Geotours presented in geocaching.com & 2 & 0.3 \\
\hline Make the choice through Geoevents that were happen & 3 & 0.6 \\
\hline Others & 5 & 0.8 \\
\hline \multicolumn{3}{|l|}{ Willingness to take a travel for geocaching in the future } \\
\hline Totally unwilling & 12 & 2.0 \\
\hline Not very unwilling & 13 & 2.1 \\
\hline Unwilling & 23 & 3.8 \\
\hline Nor unwilling nor willing & 76 & 12.4 \\
\hline Willing & 128 & 20.9 \\
\hline Very willing & 126 & 20.6 \\
\hline Totally willing & 234 & 38.3 \\
\hline
\end{tabular}

higher tendency than the others to already made a travel with the main intention to practice geocaching. Results of the association between socio-demographic and other geocaching travel behaviour indicators do not present statistically significant results.

\section{Geocaching motivations}

A set of 26 items were used to analyse geocaching motivations (Schneider, Silverberg and Chavez, 2011). Five dimensions were identified (Table 4 ) explaining $61.9 \%$ of total variance. The dimensions were named as follows: "escape", "sociability", "independency/ self-expression", "challenge/ adventure", and "culture/ learning".

All 26 motivation items listed were rated at least moderately important to respondent's geocaching participation, excepting the motives - "to be away from other people" $(M=2.5 \pm 1.7)$, "to be on my own" $(M=3.3 \pm 2)$ and "to experience solitude" $(M=3.7 \pm 1.9)$, all included in the independency/self-expression dimension
(Table 4). On other hand, the main motives observed were "to enjoy the scenery of the woods" $(M=6.1 \pm 0.98)$; "to experience nature" $(M=6.1 \pm 0.99)$, "to be close to nature" $(M=5.9$ \pm 1.1 ) and "to get away from the usual demands of life" ( $M=5.9 \pm 1.2)$, all motives included in the escape dimension. Comparing these results with results presented in other studies, can be considered that the main motives to participating in geocaching activities in Portugal are similar with the main motivations to participate in geocaching in other countries (Schneider, Silverberg \& Chavez, 2011), as in nature sports activities in Portugal (Melo \& Gomes, 2017).

The five dimensions of geocaching motivations obtained by PCA are now used to be compared between socio-demographic characteristics of geocachers (Table 5). Results show statistical differences between male and female groups in "escape" $\left(F_{(1,611)}=5.514 ; p\right.$-value $=0.019 ; \eta^{2}=$ 0.009 ; Power $=0.758$; very small dimension of the effect), "sociability" $\left(F_{(1,611)}=5.070 ; p\right.$-value 
Table 4. PCA results for geocaching motivations ${ }^{a}$

\begin{tabular}{|c|c|c|c|c|c|c|}
\hline $\begin{array}{l}\text { Principal } \\
\text { Components }\end{array}$ & Variables & $\begin{array}{l}\text { Mean } \\
\text { Score }\end{array}$ & SD & Loadings & $\begin{array}{l}\text { Variance } \\
(\%)\end{array}$ & $\begin{array}{l}\text { Cronbach's } \\
\text { alpha }\end{array}$ \\
\hline \multirow[t]{7}{*}{ Escape } & $\begin{array}{l}\text { 1. To enjoy the scenery of the } \\
\text { woods }\end{array}$ & 6.1 & 1.0 & 0.655 & 16.1 & 0.810 \\
\hline & 2. To get exercise & 5.2 & 1,4 & 0.612 & & \\
\hline & 4. To experience nature & 6.1 & 1,0 & 0.679 & & \\
\hline & 7. To feel healthier & 5.3 & 1,4 & 0.596 & & \\
\hline & 8. To be close to nature & 5.9 & 1,1 & 0.659 & & \\
\hline & $\begin{array}{l}\text { 11. To get away from the usual } \\
\text { demands of life }\end{array}$ & 5.9 & 1.2 & 0.452 & & \\
\hline & 15. To relax physically & 5.4 & 1,4 & 0.579 & & \\
\hline \multirow[t]{6}{*}{ Sociability } & $\begin{array}{l}\text { 6. To participate in recreational } \\
\text { activities }\end{array}$ & 5.2 & 1,4 & 0.452 & 14.7 & 0.828 \\
\hline & 14. To do something with my family & 4.9 & 1.7 & 0.624 & & \\
\hline & $\begin{array}{l}\text { 18. To be with people who enjoy } \\
\text { the same things I do }\end{array}$ & 5.3 & 1.5 & 0.719 & & \\
\hline & $\begin{array}{l}\text { 20. To share my skill and } \\
\text { knowledge with others }\end{array}$ & 4.5 & 1.6 & 0.567 & & \\
\hline & $\begin{array}{l}\text { 22. To be with members of my } \\
\text { group }\end{array}$ & 4.8 & 1.6 & 0.768 & & \\
\hline & 26. To meet new people & 4.7 & 1.7. & 0.603 & & \\
\hline \multirow{5}{*}{$\begin{array}{l}\text { Independencyl } \\
\text { self-expression }\end{array}$} & 19. To experience solitude & 3.7 & 1.9 & 0.820 & 11.9 & 0.812 \\
\hline & $\begin{array}{l}\text { 21. To think about my personal } \\
\text { values }\end{array}$ & 4.0 & 1.8 & 0.595 & & \\
\hline & 23. To be away from other people & 2.5 & 1.7 & 0.775 & & \\
\hline & 24. To be on my own & 3.3 & 2.0 & 0.878 & & \\
\hline & $\begin{array}{l}25 . \text { To be creative by doing } \\
\text { something such as sketching, } \\
\text { painting, taking photographs }\end{array}$ & 4.1 & 1.9 & 0.453 & & \\
\hline \multirow[t]{6}{*}{$\begin{array}{l}\text { Challenge/ } \\
\text { adventure }\end{array}$} & $\begin{array}{l}\text { 3. To experience new and different } \\
\text { things }\end{array}$ & 5.8 & 1,1 & 0.619 & 10.7 & 0.840 \\
\hline & 5. To test my skills and abilities & 5.1 & 1.4 & 0.788 & & \\
\hline & 9. To challenge myself & 5.0 & 1.6 & 0.798 & & \\
\hline & 12. To use my own equipment & 4.0 & 1.7 & 0.483 & & \\
\hline & $\begin{array}{l}\text { 16. To have a wilderness } \\
\text { experience }\end{array}$ & 5.7 & 1,1 & 0.532 & & \\
\hline & 17. To have thrills and excitement & 5.6 & 1,3 & 0.505 & & \\
\hline \multirow[t]{2}{*}{$\begin{array}{l}\text { Culture/ } \\
\text { learning }\end{array}$} & $\begin{array}{l}\text { 10. To learn about the natural } \\
\text { history of the area }\end{array}$ & 5.6 & 1.3 & 0.841 & 8.5 & 0.916 \\
\hline & $\begin{array}{l}\text { 13. To learn about the cultural } \\
\text { history of the area }\end{array}$ & 4.0 & 1.7 & 0.817 & & \\
\hline
\end{tabular}

$=0.025 ; \eta^{2}=0.008 ;$ Power $=0.727$; very small dimension of the effect) and "independency/ self-expression" $\left(F_{(1,611)}=18.778 ; p\right.$-value $=$ $0.000 ; \eta^{2}=0.030 ; \quad$ Power $=0.996 ;$ small dimension of the effect) geocaching motivation dimensions. In terms of these sex differences, men appear to be more motivated by "independency/ self-expression" than women as described in other studies (O'Connell, 2010). The findings from this study also support other results (O'Connell, 2010; Melo, 2013) that noted that women were motivated by the chance to escape (i.e. to enjoy or experience nature; to get exercise and feel healthier; to get away from the usual demands of life and; to relax) more than men. Female group also value more "sociability" dimension comparing with male group. One can hypothesise that geacaching can provide for women a more 'intimate' experience with the nature, to get 
away from the usual demands of life and provide the opportunity to meet new people.

Statistically significant differences among age groups are just observed in "escape" dimension $\left(F_{(3,609)}=2,397 ; p\right.$-value $=0,067 ; \eta^{2}=0,012 ;$ Power $=0,599 ;$ small dimension of the effect) between 18-30 years and 31-43 years groups. The second group is the one that most value this dimension while the first is the one that less values this dimension. This could occur because $31-43$ years group is the one that is most exposed to professional and social/ familiar pressures and uses geocaching to "get

Table 5. Comparison of sociodemographic characteristics through geocaching motivation.

\begin{tabular}{|c|c|c|c|c|c|}
\hline \multirow{2}{*}{$\begin{array}{l}\text { Sociodemographic } \\
\text { Characteristics }\end{array}$} & \multicolumn{5}{|c|}{ Dimensions of Geocaching Motivations } \\
\hline & Escape & Sociability & $\begin{array}{l}\text { Independency/ } \\
\text { self-expression }\end{array}$ & $\begin{array}{l}\text { Challengel } \\
\text { adventure }\end{array}$ & $\begin{array}{l}\text { Culture/ } \\
\text { learning }\end{array}$ \\
\hline G1. Male & -0.0742520 & -0.0712230 & 0.1356070 & 0.0372092 & 0.0494816 \\
\hline$\underset{0}{\times}$ G2. Female & 0.1202629 & 0.1153570 & -0.2196369 & -0.0602662 & -0.0801433 \\
\hline ら ANOVA & $5.514^{*}$ & $5.070^{*}$ & $18.788^{*}$ & 1.375 & 2.437 \\
\hline Pos-hoc test & $\mathrm{G} 1<\mathrm{G} 2$ & $\mathrm{G} 1<\mathrm{G} 2$ & $\mathrm{G} 1>\mathrm{G} 2$ & NSD & NSD \\
\hline G1. 18-30 & -0.0999397 & 0.0133275 & -0.0933311 & 0.1184140 & -0.0694484 \\
\hline G2. 31-43 & 0.1219384 & 0.0182830 & 0.0202724 & -0.0966060 & 0.0003332 \\
\hline 。 G3. 44-56 & 0.0978296 & -0.2482633 & 0.4280923 & -0.2555869 & 0.2556102 \\
\hline \& G4. >56 & -0.0622194 & 0.4287494 & 0.2510808 & -0.2412402 & 0.7944908 \\
\hline ANOVA & $2.397^{\star *}$ & 1.814 & $4.511^{*}$ & $3.625^{*}$ & $4.046^{*}$ \\
\hline Pos-hoc test & $\mathrm{G} 1<\mathrm{G} 2^{* *}$ & NSD & NSD & NSD & NSD \\
\hline G1. $9^{\text {th }}$ grade or less & 0.0197738 & 0.0760377 & 0.2108858 & 0.0578371 & -0.1940895 \\
\hline $\bar{\Phi}$ G2. Secondary School & -0.0387741 & 0.1161717 & 0.0853822 & 0.1016501 & -0.0319422 \\
\hline$\underset{c}{\gtrsim}$ G3. Higher Education & 0.0316150 & -0.0449783 & -0.0858608 & -0.1274508 & -0.0047319 \\
\hline 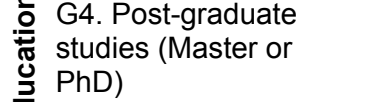 & 0.0092584 & -0.3052807 & -0.1461391 & 0.0570887 & 0.2711385 \\
\hline 离 ANOVA & 0.213 & $3.554^{*}$ & $2.457^{\star \star}$ & $2.338^{* *}$ & $2.421^{* *}$ \\
\hline Pos-hoc test & NSD & $\mathrm{G} 2>\mathrm{G} 4^{*}$ & NSD & $\mathrm{G} 2>\mathrm{G} 3{ }^{* *}$ & NSD \\
\hline G1. Worker to other & 0.0465765 & 0.0029259 & 0.0270739 & -0.0126285 & 0.0770976 \\
\hline 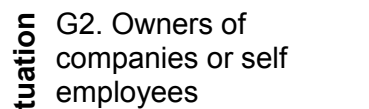 & -0.0533548 & -0.3266631 & -0.0385333 & -0.1766540 & -0.0369005 \\
\hline G3. Student & -0.0837698 & 0.0313372 & 0.0057034 & 0.1549321 & -0.2803078 \\
\hline 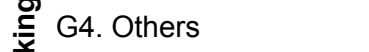 & -0.0402780 & 0.2228414 & -0.1089019 & -0.0432327 & 0.1276325 \\
\hline 늠 ANOVA & 0.641 & $3.553^{*}$ & 0.403 & 1.712 & $4.390^{*}$ \\
\hline 3 Pos-hoc test & NSD & $\mathrm{G} 2<\mathrm{G} 4^{*}$ & NSD & NSD & $\begin{array}{r}\mathrm{G} 1>\mathrm{G} 3^{*} \text { and } \\
\mathrm{G} 3<\mathrm{G} 4^{*}\end{array}$ \\
\hline G1. Without income & -0.0130639 & 0.1443658 & -0.1406617 & 0.2445984 & -0.2192670 \\
\hline $\mathrm{G} 2 .<500 €$ & -0.0104918 & 0.0416843 & 0.0923791 & 0.1945700 & 0.1495173 \\
\hline G3. $501 €<1000 €$ & 0.0192637 & 0.0043610 & -0.0741606 & 0.0155892 & 0.0536740 \\
\hline G4. $1001 €<1500 €$ & 0.1141063 & 0.0245608 & 0.0740824 & -0.1232881 & 0.0025531 \\
\hline @ G5. >1500€ & -0.1079900 & -0.1839842 & 0.3020588 & -0.2864095 & -0.0391588 \\
\hline हू G6. DK/DA & -0.2245907 & -0.1220037 & 0.0159138 & -0.0124444 & -0.0948918 \\
\hline$\stackrel{\subseteq}{\subseteq}$ ANOVA & 1.002 & 0.821 & 1.725 & $2.424^{*}$ & 1.139 \\
\hline Pos-hoc test & NSD & NSD & NSD & $\begin{array}{r}\mathrm{G} 1>\mathrm{G} 3 ; \mathrm{G} 1>\mathrm{G} 4 \\
\mathrm{G} 1>\mathrm{G} 5 ; \mathrm{G} 2>\mathrm{G} 3 \\
\mathrm{G} 2>\mathrm{G} 4 ; \mathrm{G} 2>\mathrm{G} 5 \\
\mathrm{G} 4<\mathrm{G} 6 \text { and } \\
\mathrm{G} 5<\mathrm{G} 6\end{array}$ & NSD \\
\hline
\end{tabular}

*Significant at the 0.05 level; ${ }^{* *}$ Significant at the 0.10 level; NSD - There are no statistical differences between groups. 
away from the usual demands of life".

Within the different education levels groups there are statistical differences in the "sociability" $\left(F_{(3,609)}=3.554 ; p\right.$-value $=0.014 ; \eta^{2}$ $=0.017 ;$ Power $=0.787$; small dimension of the effect $)$ and "challenge/ adventure" $\left(F_{(3,609)}=\right.$ $2.404 ; p$-value $=0.065 ; \eta^{2}=0.012 ;$ Power $=$ 0.604 ; small dimension of the effect) dimensions. Individuals with secondary education level are the ones that more value sociability, while individuals with post-graduate studies are the ones that less values this dimension. Individuals with secondary education level are also the ones that more value "challenge/ adventure" while the group with higher education studies is the one that less values this dimension.

Statistically significant differences among working situation groups are observed in "sociability" dimension $\left(F_{(3,609)}=3.553\right.$; $p$-value $=0.014 ; \eta^{2}=0.017 ;$ Power $=0.787 ;$ small dimension of the effect), and culture/ learning $\left(F_{(3,609)}=4.390 ; p\right.$-value $=0.005 ; \eta^{2}=0.021$; Power $=0.873$; small dimension of the effect). Owners of companies or self-employed are the ones that less value the "sociability" dimension, while others (i.e. retired) are the ones that most value this dimension. Students are the group that less value "culture/ learning" dimension while the group that are working for others and the others group (i.e. retired), are the ones that most value this dimension.

Results also show statistically significant differences among different incomes groups in "challenge/ adventure" dimension $\left(F_{(5,607)}=\right.$ $2.424 ; p$-value $=0.034 ; \eta^{2}=0.020 ;$ Power $=$ 0.769 ; small dimension of the effect). Statistical differences were observed between the group without income with individuals with higher incomes $(>1500 €)$. Individuals with no income are the group that most value "challenge/ adventure" dimension and individuals with higher incomes $(>1500 €)$ are the group that less value this dimension. There are also observed a decreasing of the valorisation of this dimension with the increase of the income.

\section{Conclusion}

This study aimed to respond to the need of a better understanding of geocaching, given the size of this activity and its capacity to produce economic impact especially in less developed areas. By comparing the differences between socio-demographic characteristics and geocaching profile, travel behaviour and motivations, this study unveiled information that can be used by the destinations and sport tourism companies to implement managerial actions and marketing strategies for capturing or retaining geocachers.

Findings of this study indicate that the sociodemographic characteristics of geocachers are similar to those from other nature sports participants in Portugal (Melo, 2013), characterized mainly by male participants, young individuals with decreasing participation with the increase of the age, with very high education, and working to others. In this regard, the potential of the geocaching is very attractive given the socio-demographic composition of their participants (with more educational qualifications) that allow having more sustainable behaviours in the local of the geocaching practices, as described in other studies (Melo, 2013; Pociello, 1981).

Results of this study show that geocaching in Portugal is a recent activity and it is practiced by geocachers in an early stage, that have started to practice mainly because of their group of sociability (friends, colleagues or family), generally practicing accompanied by individuals of this group or with their partner, and catching mainly traditional caches. This study also confirms that geocachers have a strong disposition to travel, not only because the majority of respondents have travelled in the past to practice geocaching, but also most of them reported their willingness to take a geocaching trip in the future, highlighting the potential of geocaching for sport tourism.

The relevant motivations regarding geocaching participation were also identified. The geocachers motivations are similar to other nature sports participants (Melo \& Gomes, 2017), mostly related to nature interest (e.g., to enjoy the scenery of the woods, to experience nature and, to be close to nature) and escape (e.g., to get away from the usual demands of life). Additionally, given the recent emphasis on physical fitness and health promoted by public 
institutions (European Union; World Health Organization; American College of Sports Medicine; among others), the physical activity element associated with geocaching is of interest and identifies geocaching as a possible addition to the suite of existing physical experience opportunities in natural and outdoor areas.

Statistical tests revealed that sociodemographics are not associated with geocaching practice profile and travel behaviour. However, several statistically significant differences were observed when comparing sociodemographic variables among the five geocaching motivation dimensions. This data can support future work in geocachers segmentation based on their motivations, providing important information for the decision making process by several actors of the territories where the geocaching activities occur. This data also has the potential to improve some destination resources to better suit geocachers.

\section{References}

Boulaire, C., \& Hervet, G. (2012). New Itinerancy: the Potential of Geocaching for Tourism. International Journal of Management Cases, 14(4), 210-218.

Broda, H. (2007) Schoolyard-enhanced learning: Using the outdoors as an instructional tool, k-8. Portland: Stenhouse Publishers.

Buckley, R. (2012). Rush as a Key Motivation in Skilled Adventure Tourism: Resolving the Risk Recreation Paradox. Tourism Management, 33, 961-970.

Cameron, L. (2011). The Geocaching Handbook: The Guide for Family Friendly, HighTech Treasure Hunting. Guildford: Globe Pequot Press.

Chang, H \& Huang, Y. (2012). Paragliding Adventure Recreation Consumers' Activity Motivation, Enduring Involvement and Their Involved Behavior. The Journal of International Management Studies, 7(2), 6174.

Chavez, D., Courtright, R., and Schneider, I. (2004). Over the river and through the woods. Parks \& Recreation, 39 (4), 68-72.

Chavez, D., Schneider, I., and Powell, T. (2004). The social psychology of a technology driven outdoor trend: Geocaching in the USA. In Proceedings of HICSS, 2004, Honolulu, HI.

Clough, G. (2010). Geolearners: Locationbased informal learning with mobile and social technologies. IEEE Transactions on Learning Technologies, 3(1), 33-44.

Crompton, J. (1979). Motivations for pleasure vacation. Annals of Tourism Research, 6(4), 408-424.

Fernandes, J. (2013). Geocaching, Novas Práticas Espaciais e Potencial Modelação da Imagem dos Lugares. Espaço \& Geografia, 16(1), 279-305.

Flucker, M. \& Turner, L. (2000). Needs, Motivations, and Expectations of a Commercial Whitewater Rafting Experience. Journal of Travel Research, 38(4), 380-389.

Geopt.org (2014). Evolução de Geocachers em Portugal. Retrieved from: http://www.geopt.org/index.php/history/evolu cao-de-geocachers-em-portugal

Groundspeak Inc. (2014). Geocaching 101. Retrieved from: https://www.geocaching.com/guide/

Ihamäki, P. (2007). Geocaching at the Institute of Paasikivi - new Ways of Teaching GPS Technology \& Basics of Orientation In Local Geography. In M. Jemni (Ed.), ICTA07. New Trends in Information and Communication Technology \& Accessibility (pp. 155-158). Tunis: Hammamet.

Ihamäki, P. (2008). Geocaching - A new Experience Designed for Enchanted Sports Tourism. World Journal of Tourism Leisure and Sport, 2(1), 53-56.

Ihamäki, P. (2012). Geocachers: the Creative Tourism Experience. Journal of Hospitality and Tourism Technology, 3(3), 152-175.

Ihamäki, P. (2013). Geocachers' creative experiences along coastal road in Finland. International Journal of Leisure and Tourism Marketing, 3(3), 282-299.

Ihamäki, P. (2014). GameFlow Experience Model: Understanding Player Enjoyment in Pervasive Adventure Games. International Journal of Wireless and Mobile Computing, 7(6), 536-548.

Ihamäki, P. (2015). User Experience of Geocaching and its Impplications to Tourism and Education (Unpublished doctoral dissertation). University of Turku, Finland. 
Ihamäki, P. \& Luimula, M. (2014). Players' Experiences in a Sports Geocaching game. In K. Blashki \& P. Isaías (Eds.), Emerging Research and Trends in Interactivity and the Human-Computer Interface (pp. 127-143). Hershey: IGI Global Publishing.

Ihamäki, P. \& Tuomi, P. (2009). Understanding 21st Century's Mobile Games within Boundaries. Breaking New Ground: Innovation in Games, Play, Practice and Theory. Proceedings of the DIGRA 2009. Brunel University, United Kingdom. Retrieved from: http://www.digra.org:8080/ Plone/dl/db/09287.32562.pdf

International Telecommunication Union. (2015). ICT facts and figures. Retrieved from: https://www.itu.int/en/ITU-

D/Statistics/Documents/facts/ICTFactsFigur es2015.pdf

Kelley, M. (2006). Local treasures: Geocaching across America. Santa Fe: Center for American Places.

Lary, L. (2004). Hide and seek: GPS and geocaching in the classroom. Learning \& Leading with Technology, 31(6), 14-18. Retrieved from: http://files.eric.ed.gov/ fulltext/ EJ695752.pdf

Louv, R. (2008). Last child in the woods: Saving our children from nature-deficit disorder. Chapel Hill: Algonquin Books of Chapel Hill.

Marôco, J. (2011). Análise estatística com SPSS statistics. Pêro Pinheiro: ReportNumber.

Mayben, R. (2010) Instructional geocaching: An analysis of GPS receivers and tools for technology integration into a middle school classroom (Unpublished doctoral dissertation). Department of Educational Leadership, Policy and Technology Studies in The Graduate School of The Univeristy of Alabama, USA.

McCarthy, B. \& McCarthy, D. (2005). Teaching around the $4 M A T \AA$ cycle: Designing instruction for diverse learners with diverse learning styles. Thousand Oaks: Corwin Press.

Melo, R. (2013). Desportos de Natureza e desenvolvimento local sustentável: Análise dos praticantes e das organizações promotoras dos desportos de natureza. (Unpublished doctoral dissertation). Universidade de Coimbra.
Melo, R. (2017). Understanding Nature Sports Participation: A Literature Review. In R. Melo \& C. Sobry (Eds.), Sport Tourism: New Challenges in a Globalized World (pp. 241275). Cambridge: Cambridge Scholars Publishing.

Melo, R. \& Gomes, R. (2017). Nature Sports Tourism Participation: Understanding Demand, Practice Profile, Motivations and Constraints. European Journal of Tourism Research, 16, 108-135.

O'Connell, T. (2010). The effects of age, gender and level of experience on motivation to sea kayak. Journal of Adventure Education and Outdoor Learning, 10(1), 51-66.

O'Hara, K. (2008). Understanding Geocaching Practices and Motivations. SIGCHI Conference on Human Factors in Computing Systems (pp. 1177-1186). Florence: ACM New York.

Pearce, P., Morrison, A. \& Rutledge, J. (1998). Tourism: Bridges across Continents. Sydney: McGraw-Hill.

Pergams, O. \& Zaradic, P. (2006). Is love of nature in the U.S. becoming love of electronic media? 16-year downtrend in national park visits explained by watching movies, playing video games, internet use, and oil prices. Journal of Environmental Management, 80, 387-393.

Pestana, M. \& Gageiro, J. (2003). Análise de dados para ciências sociais: A complementaridade do SPSS. Lisboa: Silabo.

Pociello, C. (1981). La force, l'énergie, la grâce et les réflexes. Le jeu complexe des dispositions culturelles et sportives. In C. Pociello (Ed.), Sports et société (pp. 171237). Paris: Editions Vigot.

Reams, V. \& West, S. (2008). AgencySponsored Treasure Hunts: Providing Alternatives to Traditional Geocaching. In S .Weber \& D. Harmon (Eds). Rethinking Protected Areas in a Changing World: Proceedings of the 2007 GWS Biennial Conference on Parks, Protected Areas, and Cultural Sites. Hancock: The George Wright Society.

Reeves, M. (2000). Evidencing the SportTourism Interrelationship (Unpublished Doctoral Dissertation). Loughborough University, Leicestershire, UK. 
Reynolds, Z \& Hritz, N. (2012): Surfing as adventure travel. Motivations and Lifestyles. Journal of Tourism Insights, 3(1), 1-18.

Robinson, T. \& Gammon, S. (2004). A question of primary and secondary motives: revisiting and applying the sport tourism framework. Journal of Sport Tourism, 9(3), 221-223.

Schneider, I., Silverberg, K. \& Chavez, D. (2011). Geocachers: Benefits Sought and Environmental Attitudes. LARNet, 14(1), 111.

Shaunessy, E. \& Page, C. (2006) Promoting inquiry in the gifted classroom through GPS and GIS technologies. Gifted Child Today, 29(4), $42-53$.

Shermann, E. (2004). Geocaching: Hike and Seek with Your GPS. New York: Apress.

Singer, D., G., Singer, J., L., D’Agostino, H. \& Delong, R. (2009). Children's pastimes and play in sixteen nations: Is free-play declining? American Journal of Play, 1(3), 283-312.
Trimpe, T. \& Hughes, D. (2005). GPS logic challenge. Retrieved from: http:// sciencespot.net/Media/ GPSLogicChall Teacher.pdf

Trotman, A. Jones, T. \& Handley, C. (2005). Recommending Geocaches. Proceedings of the 10th Australian Document Computing Symposium (pp. 76-83). Sydney, Australia.

Weed, M. \& Bull, C. (2004). Sports tourism: Participants, policy and providers. Oxford: Elsevier Butterworth-Heinemann.

Woratschek, H., Hannich, F. \& Ritchie, B. (2007). Motivations of sports tourists: An empirical analysis in several European rock climbing regions. University of Bayreuth. Retrieved from: http://www.fiwi.unibayreuth.de/de/download/WP_02-07.pdf 